\title{
Obstetric outcome in primigravida with unengaged versus engaged fetal head at term
}

\author{
Vandana Sai Sirisha $^{1}$, Mahantappa A. Chiniwar ${ }^{1 *}$, Sharada B. Menasinkai ${ }^{2}$
}

\begin{abstract}
${ }^{1}$ Department of Obstetrics and Gynecology, ${ }^{2}$ Department of Anatomy, Adichunchanagiri Institute of Medical Sciences and Research centre affiliated to Adichunchanagiri University, Mandya, Karnataka, India
\end{abstract}

Received: 24 October 2020

Accepted: 04 December 2020

\section{*Correspondence:}

Dr. Mahantappa A. Chiniwar,

E-mail: drmachiniwar@gmail.com

Copyright: (c) the author(s), publisher and licensee Medip Academy. This is an open-access article distributed under the terms of the Creative Commons Attribution Non-Commercial License, which permits unrestricted non-commercial use, distribution, and reproduction in any medium, provided the original work is properly cited.

\section{ABSTRACT}

Background: Labour although a physiological process can present challenges to clinician and patient. Primigravida and nulliparae are obstetric high-risk group, especially the very young and the elderly, where pregnancy and labour must be supervised. The study was done to compare the maternal and fetal outcome in primigravida with unengaged and engaged head at term.

Methods: A prospective study was done for a period of 18 months from June 2018 to December 2019 in Department of Obstetrics and Gynaecology Adichunchanagiri Institute of Medical Sciences and Research Center. 100 women with unengaged head at term (group A) and 100 women with engaged head at term (group B) as controls were selected. All the relevant data was filled in the partogram. Following observations were made, station of fetal head at the onset of labour, course of labour, duration of labour, any medical or surgical interventions or caesarean delivery. Data was analysed by SPSS 20.0 software and p value $<0.05$ was taken as statistically significant.

Results: in group A $49 \%$ and $63 \%$ in group B had vaginal delivery. $17 \%$ of group A and $14 \%$ of group B had instrumental vaginal delivery. Caesarean delivery was $34 \%$ in group A and $23 \%$ in group B. The mean total duration of labour was 13.53 hours in group A and 9.73 hours in group B. P value was 0.000 .

Conclusions: Duration of labour was more in group A than group B. Proper supervision and timely intervention in cases with an unengaged head can have vaginal delivery.

Keywords: Primigravida, Unengaged head, Primary caesarean delivery

\section{INTRODUCTION}

Labour is an important event with unique experience in a woman's life. It is characterised by uterine contractions that affect the dilatation of cervix and force the fetus through birth canal. ${ }^{1}$ Labour although a physiological process can present challenges to clinician and patient. ${ }^{2}$ Normal labour in primigravida is significantly different than multigravida, as physiologically uterus is less efficient and contractions may be irregular or hypotonic causing delay in the first stage of labour. ${ }^{3}$ Primigravida is a dark untired horse', the potential for future childbearing is determined by outcome of first labour. Hence if the first pregnancy results in normal healthy child, patient is better prepared for subsequent pregnancies. ${ }^{4}$ Primigravida and nulliparae are obstetric high risk group especially, the very young and the elderly, where pregnancy and labour must be supervised. ${ }^{5}$

Fetal head is said to be engaged when it's biparietal diameter, the greatest transverse diameter in occiput presentation, passes through pelvic inlet. Unengagement of fetal head in primigravida has long been considered as cephalo-pelvic disproportion. ${ }^{4,6}$ The traditional concept that engagement of head occurs by 38 weeks in primigravida, is not validated in clinical practice. In 
majority of primigravida, the engagement occurs between $38-42$ weeks or even during the first stage of labour. ${ }^{4,5,7-9}$

Unengagement of head in primigravida is associated with high risk of obstructed labour. Non engagement of head at the onset of active labour is a predictor of the risk of caesarean delivery. Surgical intervention is very high. Latent phase is prolonged and duration of the first phase is increased. The problems of prolonged labour are that, mother is exposed to high risk of infection, ketosis and obstructed labour, while the fetus faces the danger of asphyxia and infection. ${ }^{6}$ Dystocia or difficult labour is diagnosed in $37 \%$ of primigravida. Abnormal labour nearly affects $20 \%$ of parturients and is the most common indication for primary caesarean delivery. ${ }^{3}$ Nulliparous women typically enter labour with engaged head and obtain positive station (leading part below ischial spines) by the onset of active labour. The high station of head influences the course of labour in certain well defined ways. It has been observed that proportionate prolongation in the latent phase of labour in patients with high station. The duration of different phases of labour are longer in women with unengaged head than with engaged head. However, a substantial proportion of them deliver vaginally with no increase in maternal and fetal morbidity and mortality. ${ }^{2}$

Objectives were to compare the maternal and fetal outcome in primigravida with unengaged and engaged head at term.

\section{METHODS}

A prospective study was done for a period of 18 months from June 2018 to December 2019 in the Department of Obstetrics and Gynaecology of Adichunchanagiri Institute of Medical Sciences and Research Center. Total 200 primigravida admitted to the labour ward were included in the study. 100 women with unengaged fetal head at term (group A) and 100 women with engaged head at term (group B) as controls were selected. Written consent was taken from the patients. Ethical committee permission was taken.

\section{Inclusion criteria}

Primigravida with single live fetus with vertex presentation between 37-42 weeks of gestation, with intact membranes and no cephalo-pelvic disproportion and cervix less than $3 \mathrm{~cm}$ dilatation.

\section{Exclusion criteria}

Primigravida with skeletal deformity, multiple gestation, intrauterine growth restriction, antepartum hemorrhage, previous uterine surgeries, associated medical complications were excluded.

Detailed history regarding maternal age, period of gestation, investigation reports, USG reports were collected. General physical and obstetric examination was done.

Criteria for engagement of fetal head, as per Crichton's method $2 / 5$ th of the head should be palpable per abdomen or only one pole of the head should be palpable by 2 nd pelvic grip. On per vaginal examination, lowermost portion of head must be at or below the level of ischial spines. In case of unengaged head the position of head at $-1,-2,-3$ or free floating or mobile head was noted at the time of admission.

All the relevant data was filled in the partogram. Admission time was taken as zero hour and dilatation of cervix at the time of admission was plotted on the dilatation curve along with number of fifths palpable per abdomen.

Following observations were made, station of fetal head at the onset of labour, course of labour, duration of labour, any medical interventions (use of prostaglandins), surgical interventions (assisted vaginal delivery or caesarean delivery),mode of delivery, maternal and fetal condition were noted. The parameters were compared between both the groups. Data was analysed by SPSS 20.0 software and $p$-value $<0.05$ was taken as statistically significant.

\section{RESULTS}

Total $62 \%$ of group A and $56 \%$ of group B women were in the age group of 21-25 years. Regarding the gestational age only $20 \%$ were $>40$ weeks. $28 \%$ of group A and $32 \%$ of group B were in the gestation period of 37-39 weeks. And 39-40 weeks gestation was in 52\% of group A and $46 \%$ of group B women. Regarding station of head in group A women, $63 \%$ had free floating head, $29 \%$ at -2, 3 station and $8 \%$ of women at -1 station. All the patients in group B had vertex at 0 station.

Table 1: Percent of mode of delivery in both groups.

\begin{tabular}{|llll|}
\hline Mode of delivery & Group A & Group B & P value \\
\cline { 1 - 3 } Vaginal delivery & $49 \%$ & $63 \%$ & \\
\cline { 1 - 3 } Assisted delivery & $17 \%$ & $14 \%$ & \\
\cline { 1 - 3 } $\begin{array}{l}\text { Caesarean } \\
\text { delivery }\end{array}$ & $34 \%$ & $23 \%$ & \\
\cline { 1 - 3 } Total & $100 \%$ & $100 \%$ & \\
\hline
\end{tabular}

There was no cervical dilatation in 1 case each in both the groups. $1 \mathrm{~cm}$ dilatation was seen in $36 \%$ in group A and $22 \%$ in group B, $2 \mathrm{~cm}$ dilatation was seen in $47 \%$ in group A and $44 \%$ in group B and $3 \mathrm{~cm}$ in $16 \%$ in group A and $33 \%$ in group B.

Spontaneous onset of labour was observed in $40 \%$ in group A and $63 \%$ in group B. Induction of labour with PGE2 gel was used for 53\% in group A and $37 \%$ in group B. The mean total duration of labour was 13.53 hours in 
group A and 9.73 hours in group B (p-value.0.000 highly). First stage of labour was $12.98 \pm 3.72$ hours in group A and 8.91 \pm 2.92 hours in group B (p value.0.000). There was not much difference in duration of second and third stage of labour in both groups. Mode of delivery was not statistically significant in both groups.

Table 2: Indications for caesarean delivery in both groups.

\begin{tabular}{|c|c|c|c|}
\hline $\begin{array}{l}\text { Indications for } \\
\text { caesarean delivery }\end{array}$ & Group A & Group B & P-value \\
\hline Fetal distress & $44.1 \%$ & $56.5 \%$ & \multirow{4}{*}{0.587} \\
\hline Failure to progress & $44.1 \%$ & $21.7 \%$ & \\
\hline $2^{\text {nd }}$ stage arrest & $4 \%$ & $5 \%$ & \\
\hline Total & $34 \%$ & $23 \%$ & \\
\hline
\end{tabular}

Table 3: APGAR score at 1 minute and 5 minutes in both groups.

\begin{tabular}{|llll|}
\hline APGAR score & Group A & Group B & P value \\
\hline At 1 minute & $6.98 \pm 0.14$ & $6.98 \pm 0.20$ & 1.0 \\
\hline At 5 minutes & $9 \pm 0.0$ & $8.99 \pm 0.10$ & 0.319 \\
\hline & 100 & 100 \\
\hline
\end{tabular}

Regarding maternal complications postpartum hemorrhage was observed in $4 \%$ in group $\mathrm{A}$ and $3 \%$ in group B. There were no other complications. There was no other maternal morbidity. There was no neonatal mortality. NICU admissions were 7 in group A and 3 in group B. Perinatal morbidity was nil.

\section{DISCUSSION}

The study was conducted to know the maternal outcome and fetal outcome among 200 primigravida admitted at term to labour ward. 100 women with unengaged head (group A) and 100 women with engaged head (group B) were included in the study. The results were compared with the studies reported in the literature. Regarding the maternal age, unengaged head in women $>30$ years is an added risk factor. Adita et al reported a comparative study of 110 women with unengaged head (group A) and 110 women with engaged head (group B). ${ }^{4}$ There were 15 cases in group A and 9 cases in group B with age more than 30 years. In the present study there was only 1 case each in both groups. A comparative study reported by Shahida et al, 100 cases with unengaged head (group B) and 100 cases with engaged head (group A) and all women were below 30 years of age. ${ }^{3}$ Regarding the mode of delivery in our study, $66 \%$ in group A and $74 \%$ in group B had vaginal delivery. The incidence of caesarean delivery was $34 \%$ in group A and $23 \%$ in group B. The present study is compared with studies reported by following authors. Mahendra et al, Shivamurthy et al and Iqbal et al reported a comparative study of 100 women with unengaged head (group A) and 100 women with engaged head (group B). ${ }^{1,2,6}$

Table 4: Comparison of age distribution with other studies. ${ }^{3,4}$

\begin{tabular}{|lllllll|}
\hline Age (years) & Adita et al & & Shahida et al & & Present study & \\
& Gr A & Gr B & Gr B & Gr A & Gr A & Gr B \\
\hline$<\mathbf{2 0}$ & 24 & 32 & 24 & 21 & 23 & 33 \\
\hline $\mathbf{2 1 - 2 5}$ & 52 & 56 & 53 & 48 & 62 & 56 \\
\hline $\mathbf{2 6 - 3 0}$ & 19 & 13 & 23 & 31 & 14 & 10 \\
\hline$>\mathbf{3 0}$ & 15 & 09 & - & - & 01 & 01 \\
\hline Total & 110 & 110 & 100 & 100 & 100 & 100 \\
\hline
\end{tabular}

Table 5: Comparison of mode of delivery with other studies. ${ }^{1-4,6}$

\begin{tabular}{|lllllll|}
\hline \hline \multirow{2}{*}{ Authors } & Groups & $\mathbf{N}$ & $\begin{array}{l}\text { Vaginal } \\
\text { delivery }\end{array}$ & $\begin{array}{l}\text { Instrumental } \\
\text { delivery }\end{array}$ & $\begin{array}{l}\text { Caesarean } \\
\text { delivery }\end{array}$ & P value \\
\hline \multirow{2}{*}{ Adita et al } & Gr & A & 110 & 67 & - & 43 \\
\hline \multirow{2}{*}{ Mahendra et al } & Gr & B & 110 & 89 & - & 21 \\
\hline \multirow{2}{*}{ Iqbal et al } & Gr & A & 100 & 53 & 10 & 37 \\
\hline \multirow{2}{*}{ Shahida et al (Gr B unengaged) } & Gr & B & 100 & 70 & 7 & 23 \\
\hline \multirow{2}{*}{ Shivamurthy et al } & Gr & A & 100 & 47 & 15 & 38 \\
\cline { 2 - 7 } & Gr & B & 100 & 73 & 12 & 15 \\
\hline \multirow{2}{*}{ Present study } & Gr & B & 100 & 42 & 19 & 39 \\
\cline { 2 - 7 } & Gr & A & 100 & 65 & 16 & 19 \\
\hline & Gr & A & 101 & 69 & 14 & 18 \\
\cline { 2 - 6 } & Gr & B & 099 & 87 & 6 & 6 \\
\hline
\end{tabular}


Table 6: Comparing the indications for caesarean delivery., ${ }^{1,4}$

\begin{tabular}{|lllllll|}
\hline Indications & Adita et al & & Mahandra et al & \multicolumn{3}{c|}{ Present study } \\
\hline & Gr A & G r B & Gr A & Gr B & Gr A & Gr B \\
\hline Fetal distress & 9 & 11 & 14 & 12 & 15 & 13 \\
\hline Non progress of labour & 24 & 6 & 18 & 9 & 15 & 5 \\
\hline DTA & 10 & 4 & - & - & - & - \\
\hline Failure of induction & - & - & 5 & 2 & - & - \\
\hline 2nd stage arrest & - & - & - & - & 4 & 5 \\
\hline & 43 & 21 & & & 34 & 23 \\
\hline
\end{tabular}

Table 7: Comparison of maternal complications. ${ }^{1,4,6,11}$

\begin{tabular}{|c|c|c|c|c|c|c|c|c|c|c|}
\hline \multirow[t]{2}{*}{$\begin{array}{l}\text { Maternal } \\
\text { complications }\end{array}$} & \multicolumn{2}{|c|}{ Adita et al } & \multicolumn{2}{|c|}{ Shahida et al } & \multicolumn{2}{|c|}{ Mahandra et al } & \multicolumn{2}{|c|}{ Iqbal et al } & \multicolumn{2}{|c|}{ Present study } \\
\hline & Gr A & Gr B & $\begin{array}{l}\text { Gr A } \\
\mathbf{N}=262\end{array}$ & $\begin{array}{c}\text { Gr B } \\
\mathrm{N}=1178\end{array}$ & Gr A & Gr B & Gr A & Gr B & Gr A & Gr B \\
\hline Cevical tear & 18 & 9 & $4(1.53 \%)$ & $12(1.02 \%)$ & 3 & 5 & 3 & 0 & - & \\
\hline PPH & 11 & 4 & $7(2.67 \%)$ & $17(1.44 \%)$ & 11 & 7 & 18 & 10 & 4 & 3 \\
\hline Puerperial sepsis & - & - & $3(1.15 \%)$ & $11(0.93 \%)$ & - & - & - & - & - & - \\
\hline Wound infection & - & - & $8(3.05 \%)$ & $81(6.88 \%)$ & 3 & 2 & 5 & 2 & - & \\
\hline Perineal tear & - & - & - & - & 7 & 4 & 2 & 0 & - & \\
\hline Total & 29 & 13 & 22 & 121 & 24 & 18 & 28 & 12 & 4 & 3 \\
\hline
\end{tabular}

Incidence of caesarean delivery was less in all these studies in cases with engaged head compared to unengaged head. Present study is comparable with Mahendra et al and Iqbal et al. ${ }^{1,6}$ Chaudhary et al reported a comparative study of 150 women with unengaged head (group A), 150 women with engaged head (group B). ${ }^{6}$ The incidence of caesarean delivery was $16.89 \%$ in group $\mathrm{A}$ and $5.33 \%$ in group B. The indication for caesarean delivery in $48 \%$ cases was due to failure to progress ( $p$ value 0.000). The common indications for caesarean delivery in group $\mathrm{A}$ in our study were fetal distress and non-progress of labour, whereas in group B fetal distress was a common indication. According to Aditi et al and Mahendra et al non progress of labour was common indication in group A. ${ }^{1,4,6}$

According to Siama et al total duration of labour in $34 \%$ of group A and 74\% of group B was $<12$ hours. ${ }^{6}$ Remaining $66 \%$ in group A and $26 \%$ in group B took $>12$ hours. In the present study total duration of labour was 13.53 hours in group A and 9.73 hours in group B ( $p$ 0.000 ). According to Mahendra et al duration of 1st stage was 14.21 hours in group A and 12.5 hours in group B. ${ }^{1}$

\section{CONCLUSION}

From the present study it can be concluded that unengaged head in primigravida at term calls for constant vigilance throughout the labour by using tools such as partogram and timely medical intervention. The duration of labour is increased significantly with unengaged head. However, unengaged head should not be the sole indication for caesarean delivery. With proper counselling a good number of them can have vaginal delivery. Watchful expectancy and timely proper intervention can reduce primary caesarean delivery rate and associated maternal morbidity.

\section{ACKNOWLEDGMENTS}

Authors would like to thank the HOD of department of OBG and faculty members who helped them to collect the data and publish the article.

\section{Funding: No funding sources}

Conflict of interest: None declared

Ethical approval: The study was approved by the Institutional Ethics Committee

\section{REFERENCES}

1. Bhandra DM, Sonawane PK. Comparative study between unengaged and engaged fetal head in primigravida at term or in labour. Int $\mathbf{J}$ Reprod Contracept Obstet Gynecol. 2018;7(11):4869-74.

2. Shivamurthy HM, Asaranna D, Giridher SA, Jannu P, Jassawalla N, Himgire JR. Comparative study of labour course in primigravidae with unengaged head in active labour, with those having engaged head. Medica Inovatica. 2014;3(2):84-9.

3. Malik S, Asif U, Asif M. Primigravida; obstetrical outcome; with engaged versus unengaged fetal head with spontaneous onset of labour at term. Professional Med J. 2016;23(2):171-3.

4. Goyal A, Wadhwani R. Maternal outcome of Primigravida patient with term pregnancy with engaged versus unengaged fetal head at onset of 
labour. Int J Reprod Contracept Obstet Gynecol. 2019;8(8):3037-40.

5. Adeyami AS, Adekanle AD, Afolabi AF. Predictors of Vaginal delivery in nulliparous mothers. Annals African Med. 2014;13:35-40.

6. Iqbal S, Sumaira S. Outcome of primigravida with unengaged versus engaged fetal head at term or onset of labour. Biomedica. 2009;25:159-62.

7. Unnisa S, Pornima MS. Unengaged head at term in Primigravida: does it affect the chance of having a normal delivery? Int J Reprod Contracept Obstet Gynecol. 2019;8(4):1616-9.

8. Shaikh F, Shaikh N, Shaikh S. Outcome of Primigravida with high head at term. J Pak Med Asso. 2014;64 (9):34-8.
9. Ambvani B. Primigravidas with floating head at term or onset of labour. Internet $\mathbf{J}$ Obst Gynae. 2003;3(1):1-4.

10. Chaudhary S, Farrakh R, Dar A, Humayun S. Outcome of labour in nullipara at term with unengaged head. J Ayub Medical College Abbottabad. 2009;21(3):131-4.

11. Banu DS, Sultana R, Khatun M, Khanam S, Chowdhary F, Nazneen S, et al. Maternal outcome of among the primigravida woman presented with fetal head engagement: experience of 1440 cases in Bangladesh. J Sci Foundation. 2018;16(2):34-7.

Cite this article as: Sirisha VS, Chiniwar MA, Menasinkai SB. Obstetric outcome in primigravida with unengaged versus engaged fetal head at term. Int J Reprod Contracept Obstet Gynecol 2021;10:251-5. 